\title{
A Literature Review of the Connotation Dimensions of Entrepreneur Concepts in the Context of Confucian Culture
}

\author{
Feng Hao \\ Department of Business Administration, School of Management, Jinan University, Guangzhou, China \\ Email: m13129309644@qq.com
}

How to cite this paper: Hao, F. (2019) A Literature Review of the Connotation Dimensions of Entrepreneur Concepts in the Context of Confucian Culture. American Journal of Industrial and Business Management, 9, 1094-1110.

https://doi.org/10.4236/ajibm.2019.94075

Received: April 8, 2019

Accepted: April 26, 2019

Published: April 29, 2019

Copyright () 2019 by author(s) and Scientific Research Publishing Inc. This work is licensed under the Creative Commons Attribution International License (CC BY 4.0). http://creativecommons.org/licenses/by/4.0/

\begin{abstract}
Entrepreneurs are the backbone of reform and opening up and have made significant contributions to the prosperity of China's economy. However, entrepreneurial theory is an exotic product that is rooted in Western culture. So, in the context of Confucian culture, how is the concept of entrepreneurs defined? What is the similarity between its connotation and the Western "entrepreneur"? Excavating the characteristics of "entrepreneur" under the background of Confucian culture is not only the need to construct the management theory of Chinese characteristics, but also has great practical significance for the cultivation and creation of Chinese entrepreneurs. This study cuts through the Confucian cultural perspective, and comprehensively and systematically sorts out the development of entrepreneurial theories in each period, with a view to drawing lessons from the entrepreneurial theory under the Confucian cultural context.
\end{abstract}

\section{Keywords \\ Confucian Culture, Entrepreneur, Review}

\section{Introduction}

On September 8, 2017, the Central Committee of the Communist Party of China and the State Council issued the "Opinions on Building an Entrepreneur Healthy Growth Environment, Promoting Outstanding Entrepreneurship, and Giving Full Play to the Role of Entrepreneurs". The "Opinions" pointed out that entrepreneurs are an important subject of economic activities. Since the reform and opening up, a large number of outstanding entrepreneurs have grown rapidly in the market competition. A large number of enterprises with core com- 
petitiveness have emerged, making important contributions to accumulating social wealth, creating jobs, promoting economic and social development, and enhancing overall national strength. It is of great significance to create an environment for entrepreneurs to grow up healthily, to promote outstanding entrepreneurship, and to give full play to the role of entrepreneurs, to deepen supply-side structural reforms, stimulate market vitality, and achieve sustained and healthy economic and social development. The party and the government have highly affirmed the status and role of entrepreneurs. This is the first time in the 40 years of reform and opening up, indicating that this group of entrepreneurs has made tremendous contributions to China's economic growth.

This article consists of the following parts:

The first part is the research innovation, research significance, research contribution and research deficiency of this paper. In the second part, this paper reviews the related research of entrepreneurs, including the study of entrepreneurs in China and the West, the study of entrepreneurs in cultural contexts, and the study of entrepreneurs in the context of Confucian culture. In the third part, this paper combines the above-mentioned literatures and concludes that it is found that the research on the connotation dimension of entrepreneurial concept under Confucian culture has great research significance.

\subsection{Research Innovation}

There are many related researches on entrepreneurs, but most of them are relatively homogenized. In general, they are all about entrepreneurs in the context of Western entrepreneurs. From the study of entrepreneurs in the West, they use economic methods in Western cultural contexts to study, define the definition, function and role of entrepreneurs, and form a certain entrepreneurial theory system, but due to mainstream economics neglect, late development is relatively weak. From the perspective of domestic entrepreneurs, they define entrepreneurs from a certain aspect or a certain angle, sum up the characteristics of entrepreneurs or distinguish the relationship between entrepreneurs and capitalists, but do not form a certain entrepreneurial theory system.

Therefore, based on the predecessors' research vacancies, this research has made certain innovations. First of all, from the perspective of research, this study analyzes the connotation dimension of entrepreneurial concept from the perspective of Confucian cultural scenarios. Prior to this, many scholars based on Western cultural scenarios to understand and design research, the theoretical framework is naturally with more Western cultural characteristics, said more comprehensive, but not applicable to the Chinese situation. Therefore, this study chooses from the perspective of Confucian culture, uses the concepts and ideas of Confucian culture to explain the characteristics of entrepreneurs in the Chinese context, and concludes the concept connotation that is more in line with the characteristics of Chinese entrepreneurs. Secondly, on the basis of the research content, this study summarizes the entrepreneurial concept model which is more in line with China's actual situation, and analyzes the connotation of en- 
trepreneur concept under Confucian culture and the connotation of entrepreneurs in Western cultural context. Similarities and differences prior to this study, entrepreneurial theory originated in the West and later developed in China. However, no matter in the West or China, no one has systematically combed the predecessors' research results and formed a perfect entrepreneurial theory system. Then, this study chooses the perspective of cultural differences, not only unearths the connotation of entrepreneurial concepts in two different cultures, but also sums up the conceptual elements of entrepreneurs under Confucian culture and the connotation of entrepreneurs in the western context. What are the similarities and differences? Finally, in terms of research methods, this study used multiple case studies and used rooted theory to process data, which was scientific and universally persuasive. In view of entrepreneurial theory research, most of the domestic and foreign studies are mainly through literature research and single case studies, and less are multi-case studies using grounded theory. Then, using multiple cases, in terms of the study of entrepreneurial concepts, it is better to sum up the conclusions of research under universal law.

\subsection{Research Significance}

The existing entrepreneurial theory has been relatively mature in the West, but the domestic entrepreneur theory is not perfect. Although many scholars have studied the concept of entrepreneurs, they all demonstrate the characteristics of entrepreneurs or the functions of enterprises from a certain perspective, but lack the systematic combing and summarizing the concept of "entrepreneurs". This paper cuts through the Confucian cultural context, adopts multiple case analysis methods, focuses on the life experiences of Confucian cultural entrepreneurs who have great differences with Western culture, and concludes the dimensional model of entrepreneurial concept connotation with Confucian cultural characteristics.

\subsection{Research Contribution}

The theoretical contribution of this paper is mainly to define the concept of entrepreneurial concept under the Confucian cultural situation, and to supplement this blank of the connotation model of entrepreneur concept under Confucian culture. In the past, the study of entrepreneurial theory was mainly concentrated in the Western cultural context, and the natural conclusion was the "Western Entrepreneur Theory". So, where is the theory of entrepreneurs in the Chinese context? Can we find a theory of Chinese entrepreneurs that can be applied to Confucian culture? In order to solve this problem, this study uses the multi-case research method to summarize the connotation of the concept of entrepreneurs in the Chinese context, and adds a stone to the construction of management theory with Chinese characteristics.

Specifically, the contribution of this research is mainly in two aspects: 1) enriching the domestic entrepreneurial theory's shortcomings, but also giving the Chinese entrepreneurial significance of Western entrepreneurial theory, en- 
hancing its practicability and adaptability. The theory of entrepreneurs originated in the West, and later Chinese scholars enriched them, but their research mostly expanded from the theoretical framework of Western scholars, and rarely considered the difference of unique cultural scenes in China. From the perspective of Confucian culture, we can develop a set of entrepreneurial theories that are more suitable for the Chinese environment. 2) Integrating and sorting out the research results of predecessors, making it a more practical theoretical framework. Entrepreneur theory was developed in the context of Western culture. After the introduction of China, Chinese scholars also developed the Chinese model within their inherent framework, but rarely considered Chinese cultural scenarios. 3) Summarize the similarities and differences between the conceptual elements of the two entrepreneurs. From the above analysis, the entrepreneurial conceptual models in two situations can be obtained. Further comparison can reveal the similarities and differences between their elements, and it is more convenient to understand the difference between the connotation of entrepreneurial concepts and the Western concepts in Confucian culture.

The theory of entrepreneurs originated from the West and is not adapted to the Chinese society with great cultural differences. However, the theory of domestic entrepreneurs only insists on the Chinese test of Western entrepreneurial theory. Western entrepreneurial theory pays too much attention to a certain perspective. To define entrepreneurs is not comprehensive. Therefore, from the perspective of Confucian culture, discussing the concept of entrepreneurship not only enriches the gap of domestic entrepreneurial theory, but also gives the Chinese meaning of Western entrepreneurial theory, and enhances its practicability and adaptability.

\subsection{Lack of Research}

Although there are many innovations and discoveries in this research, it is inevitable that the following research deficiencies exist, which is the direction that the research can further explore and explore in the future.

First, this paper uses a multi-case study method, but it is inevitable that there is a deficiency in the case study itself, which affects external validity. This paper selects three cases. Although it represents entrepreneurs in Confucian culture, there are still many inconsistencies in the three entrepreneurs. These places may lead to diversity of results. The three entrepreneurs selected in this study are not at the same time, and although influenced by Confucian culture, but also influenced by Western culture, it will also bring uncertain effects to the research results. In addition, the conclusions formed in this study lack empirical evidence. Therefore, future research can use empirical research methods to verify the conclusions of this study.

Secondly, this paper adopts the data processing method of grounded theory. From the concept to the formation of the category, although various measures such as continuous comparison, memorandum and multi-person decoding have 
been adopted to try to overcome the influence of subjective consciousness on the result, however, it is inevitable that it will be influenced by the subjective consciousness of the researcher and the ability of knowledge. Therefore, future research should combine qualitative research with quantitative research as much as possible to improve the value and reliability of research.

Third, the research data is all second-hand information, which is relatively single. Since the main coding materials selected in this study are biographies, historical facts, etc., the reliability and validity of the possible data are not sufficient, so it is necessary to supplement the research data.

\section{Entrepreneur Research}

As everyone knows, successful entrepreneurs play a very important role in driving economic development, growth and prosperity [1]. Since the issue of economic growth has always been a problem that the economics community has attached to, the term "entrepreneur" has attracted the attention and research of many Western scholars. Looking back on the 40 years of reform and opening up, China's economic development has achieved remarkable achievements. However, the current academic understanding of entrepreneurs still stays at the level of Western consciousness, and does not pay enough attention to the characteristics of local Confucian culture. We must know that there are huge differences between Eastern and Western cultures. Western-style entrepreneurial concepts are not well adapted to the Chineseization scene, so scholars are also actively working on the contextualization of Chinese entrepreneurs.

Since the Western economist Cantillon first proposed the concept of "entrepreneur", many famous economists have actively explored their definitions, activities, and functions, but they have not achieved a consensus in economics [2]. On the other hand, with the introduction of Western economics into China, Chinese scholars have also begun to explore the connotation and dimension of "entrepreneurs".

\subsection{Western Entrepreneur Research}

Western classical economics believes that entrepreneurs are generally risk-bearers. In the book "Business Overview", Cantillon (1775) believes that entrepreneurs are the kind of people who take the initiative to take risks [3]. The basic feature is that they buy labor and materials at an indefinite price and then sell them at contract prices, such as landlords, bakers, businessmen and other roles. So why do entrepreneurs take risks? Cantillon did not answer. Subsequently, the famous economist Smith (1776) answered from the perspective of political economy that entrepreneurs took risks to make profits [4]. Entrepreneurs strive to maximize profits in order to be self-interested, thus taking the risk of business failure. For many years thereafter, economists have discussed the risks of what entrepreneurs have undertaken, but they have not given an answer to the specific corporate functions of entrepreneurs. Based on this issue, Knight (1921) believes that 
entrepreneurs are the bearers of enterprise development uncertainty, and their main task is to decide what to do and how to do it, that is, to function as a corporate decision maker [5]. But unlike the previous economists' point of view, he believes that corporate profits are the result of entrepreneurs' uncertainty of decision-making, rather than the risk-taking return.

At the same time, in the 18th century, entrepreneurs were considered capitalists. Its supporters are Dürger and Marx. Dugel (1961) mentioned in his book "Investigation on the Formation and Distribution of Wealth" that entrepreneurs' compensation is pure capital compensation, and they are people who take risks for capital [6]. Correspondingly, Marx (1844) argued in the Economic and Philosophical Manuscripts of 1844 that competition among capitalists would reduce profits, and finally reduce interest on money, and big capitalists would gain a favorable competitive position than small capitalists [7]. The view he agrees with is the personalization of entrepreneurial capital.

The neoclassical economics believes that people should understand entrepreneurs in terms of organizational functions and personal qualities. Its representative Sai (1805) believes that entrepreneurs need to have special skills and qualities, such as judgment, professional knowledge, common sense and professional management skills [8]. These qualities are attributed to the need to act as an intermediary between producers and consumers, who must organize production, then identify target customers, and sell products to them. Chandler (1987) also emphasized the importance of entrepreneurial personal ability in capturing the market opportunities and organizational innovation during the growth of large American companies [9]. Marshall pointed out in Economic Principles (1897) that entrepreneurs are human capital [10]. Part of it must have two roles, producers and leaders. As merchants and producers, they must be able to predict changes in production and consumption based on changes in the business environment and make adjustments to guide production practices. On the other hand, as leaders in the organization, they must have extraordinary organizational and coordination skills, and can influence the enthusiasm and creativity of employees, and then control the business affairs. Sombart (1936) also believes that entrepreneurs have built organizational functions [11]. First of all, entrepreneurs are organizers, and they need to have the ability to work for him. Second, entrepreneurs must have strong communication and negotiation skills to effectively persuade others to obey their will; finally, entrepreneurs must economically good at calculation, effective control of costs, and ultimately the goal of maximizing profits, this is the highest purpose of capitalism. The above distinction between entrepreneurial organizational functions and personal qualities is based on the unbalanced state of the economy, but it does not explain what characteristics entrepreneurs should possess when the economic environment is in equilibrium [12]. It was not until the emergence of the famous economist Xiong Biao (1934) that he solved this problem [13]. He pointed out in his famous work "The Theory of Economic Development" that entrepreneurs have a 
heroic image and they should be regarded as "innovators". Innovation provides new products to guide the needs of consumers, leading to economic development events that circulate, eventually breaking the calm and balanced economic environment and producing the effect of "subversive innovation". Specifically, he also pointed out five basic types of technological innovation: 1) product innovation; 2) process innovation; 3) market innovation; 4) raw material innovation; 5) organizational management system innovation. Here, Schumpeter defines the enterprise as a tool for realizing a new combination of production methods, and the entrepreneur's function is to realize a new combination. This idea has far-reaching influence on the later scholars' research because he specifically distinguishes entrepreneurs from Capitalists, entrepreneurs and risk takers, this is a more precise definition of entrepreneurs. Later, in the 1920s, some Austrian economists defined entrepreneurs as decision makers. They believed that entrepreneurs are a type of person who predicts future market changes through imagination and inference, and their representatives have Yake, Kozner, Leibinstein, Carson. Among them, Hayek (1920) believes that entrepreneurs can rely on their incomplete information to find out the unknown market demand based on their incompetent information, in order to gain the wealth growth [14]. Similarly, Kozner (1973) created his own entrepreneurial theory based on school theory [15]. He believes that in the human purposeful behavior studied by economics, there is an entrepreneurial element, that is, entrepreneurs are alert, entrepreneurs can use it to discover potential profit opportunities in the market, and determine the price, making the transaction Can be achieved. Leibinstein (1968) proposed a straightforward concept: entrepreneurs are people who avoid others-or the inefficiencies that their organization is prone to, and thus succeed [16]. Due to the emergence of "inert areas" within the enterprise, the need for entrepreneurial functions has arisen: "fill in the blanks" and "investment fills". But unlike the previous economists, Leibinstein incorporated entrepreneurial functions into the $\mathrm{X}$ efficiency theory framework. As of this point, entrepreneurial theory has not yet formed a sound framework theory. Thus, Carson (1982) pointed out in the book "Entrepreneur: An Economic Theory" that entrepreneurs are people who make judgmental decisions on specific matters based on scarce resources [17]. The role of entrepreneurs is to make non-programmatic decisions for optimal allocation of scarce resources based on their own information acquisition and information processing capabilities in an uncertain environment. In terms of function, Carson affirmed Schumpeter's "innovative function" and also proposed the creation of market and arbitrage functions.

In the 21st century, Western economists focus on the role of entrepreneurs. Among them, Ronald H. Coase (1937) studied entrepreneurs from the perspective of property rights [18]. The existence of all organizations would cost a certain amount of money, so if they could operate in a cheaper way, entrepreneurs will exist in the form of organization. At the same time, Williamson (1999) believes that market operation is costly [19]. If entrepreneurs lead and control re- 
sources, they can reduce costs. In addition, with regard to the role played by entrepreneurs within the organization, Demsetz (1994) think that entrepreneurs are the best command of the production of people within the organization, they signed a contract with the internal staff, employees in exchange for their work with pay, and employ employee performance inputs to properly motivate employees [20].

\subsection{Research on Chinese Entrepreneurs}

Compared with the West, domestic research on entrepreneurs started late. However, combined with the actual situation in China, scholars have defined the concept of entrepreneurs from three aspects: capital model, human capital model and innovation model.

First of all, domestic scholars' research hotspots about entrepreneurs lie in the distinction between entrepreneurs and property owners. Some scholars believe that entrepreneurs should have both property rights and management rights. Zhang Chunlin (1994) believes that enterprises enjoy property ownership and decision-making power at the same time, and attribute the basic characteristics of the governance structure of state-owned enterprises in China to internal control under administrative intervention, pointing out that the essence is "entrepreneur absence" [21]. Zhang Weiying (1995) believes that entrepreneurs themselves are also capitalists [22]. Capital owners have the priority of being entrepreneurs to ensure that entrepreneurial talents occupy the position of entrepreneurs. In the case that business operations are difficult to observe, personal property can arise. Whether it is the owner who only takes risks, earns income and does not engage in business-shareholders, or managers who only engage in business management without taking risks and earning operating income, they are not entrepreneurs in a complete sense. The role of entrepreneurs is only played as a whole. In addition, he also argues that entrepreneurs are people who take risks and engage in business operations and then earn income. The role of entrepreneurs is only played as a whole. In addition, he also argues that entrepreneurs are people who take risks and engage in business operations and then earn income. From its point of view, scholars at the time believed that entrepreneurs were capitalists, and there was no difference between the two. However, some scholars believe that entrepreneurs are professional managers. Huang Qunhui (2003) conducted research on state-owned enterprise reform and entrepreneurial incentives and constraints [23]. He believed that entrepreneurs should be understood as top management or managers. Even without ambiguity, the directors and managers of state-owned enterprises are entrepreneurs. Zhou Liqun and Chen Xiaodong (2000) conducted research from the perspective of entrepreneur formation. They believed that in the process of institutional transformation in China, along with the professionalization of managers, managers not only organize production, but also discover market opportunities, product innovation, technological innovation, Organizational innovation and market 
innovation, they think managers are entrepreneurs [24]. Hong Yinxin (2000) defines entrepreneurs as professional managers with human capital [25]. Cheng Chengping and Wei Mingxia (2002) pointed out in "Entrepreneur Human Capital" that from the perspectives of entrepreneurs' functions, quality, "rights and responsibilities", economic history, identity, etc., entrepreneurs take business as a profession, and People who have a major responsibility for survival and development [26]. Entrepreneurs belong to managers, but general managers are not all entrepreneurs. Only those who meet the definition of entrepreneurs can be called entrepreneurs.

Second, some scholars try to define entrepreneurs from the perspective of human capital. Liu Maosong (1994) believes that entrepreneurs take the value-added of enterprise assets as their business goal, and combine their intellectual property (i.e. human capital) with the material property of the enterprise through the process of competition in the property rights market, thus occupying the enterprise in the operation [27]. The overall assets, independent and creative organization and command of the enterprise, according to the market for production, circulation, services and other commodity economic activities, and to undertake a specific group of business risks. Zhou Qiren (2005) believes that after the opening of the product market and the factor market, many things have changed, and we have called the human capital factor of entrepreneurs [28]. In the face of product competition, entrepreneurs must first decide who to hire and what to produce in the future. This is the most important point that reflects the human resources of entrepreneurs. Obviously, Zhou Qiren believes that entrepreneurs are an important human capital. In addition, well-known scholar Ding Donghong (1999) also expressed his views [29]. He believes that entrepreneurs are the owners of heterogeneous human capital. They believe that entrepreneurs are not static, but dynamic, and will continue to increase marginal returns. Li Zhongmin and Zhao Shen (2007) believe that entrepreneurs first acquire professional knowledge and skills through various channels, accumulate experience in long-term practice, and form a special kind of capital through the eyes and charm formed by practice [30]. Entrepreneur's human capital, the value of this capital far exceeds other types of human capital, has become the most important capital.

Again, some scholars believe that entrepreneurs are people with certain qualities. Zhang Dingding (1998) believes that entrepreneurs are entrepreneurs with entrepreneurial talent [31]. The so-called entrepreneurship can be composed of several kinds of abilities, including: 1) operational ability. Such as leadership organizational capabilities, coordination and control capabilities, environmental adaptability, etc. 2) Innovative capabilities, including the ability to identify opportunities and achieve profit through innovation. 3) The ability to take risks and identify risks. Li Yining (1999) believes that entrepreneurs are a quality, not a position [32]. The four conditions that entrepreneurs must possess are: vision, courage, organized human capital, and social responsibility. Wang Guocheng 
(2002) believes that entrepreneurs are a concept that is constantly being given new ideas by history [33]. Entrepreneurs in the modern sense refer to professional managers who engage in innovative activities. They can be natural or collective. The basic quality is "Innovation". Cheng Guoping (2002) believes that entrepreneurs refer to the excellent operators in the company, and regard the position, management ability and contribution as the three basic conditions for measuring entrepreneurs [34].

Finally, some domestic scholars believe that entrepreneurs are actually an intangible asset of enterprises. For example, domestic scholar Xu Zhijian (1997) believes that entrepreneurs are actually an "intangible asset" within an enterprise [35]. Entrepreneur's intangible assets are the source of entrepreneurial innovation profits, because entrepreneurs' intangible assets themselves represent the entrepreneur's own sense of innovation, desire, ability and success.

Judging from the above-mentioned Western entrepreneur research and Chinese entrepreneur research, the Chinese academic community's understanding of entrepreneurs is limited to Western entrepreneurial theories. The reality is that there is a clear difference between Western culture and mainstream Confucian culture in Chinese culture. It is not objective to use Western theoretical dimensions to analyze China's actual situation. Therefore, in order to study the problem of Chinese entrepreneurs, we must consider the Confucian cultural dimension in the Chinese context and grasp its deep influence on Chinese people's mind, spirit and behavior.

\section{Entrepreneur in a Cultural Context}

Culture is the consciousness, behavior and values that are acquired within a social group through learning. Since mankind, world culture can be divided into four major systems: Chinese culture, Indian culture, Islamic choice culture and European and American culture. The cultures of Japan, North Korea, South Korea and Vietnam belong to Chinese culture. Together with Islamic culture and Indian culture, these three are collectively referred to as Confucian culture. From ancient Greece to today's European and American culture, it can be called Western culture, The third culture [36].

Therefore, entrepreneurs are in different cultural environments and have different qualities, which lead to differences in entrepreneurial definitions. Specifically, in the Western culture, due to the influence of religious beliefs, entrepreneurs show a more interest-oriented, and make money as a "vocational duty" in life; but in the context of Confucian culture, advocating "making money" is for the welfare of society. The improvement of the self-spiritual realm is a highly altruistic spirit, so entrepreneurs have a homeland feeling.

\subsection{Western Cultural Characteristics}

The Western culture referred to in this article refers specifically to the culture represented by the United States, because the United States is an emerging pow- 
er with a history of only two hundred years and developed economy. Its dominant culture is European culture [37], and the entrepreneurial theory is mainly the source.

Human beings have a variety of cultural patterns, each with its own distinctive characteristics. First of all, the United States is an open immigrant country, and its immigration background has created its diversity and openness. In addition, American society and religion are inextricably linked, and religion has a great impact on American culture. As we all know, Americans believe in Christianity, and most of them are descendants of the Puritans. Richard John Newhouse pointed out: "One of the most basic facts about the United States is that in the Americans' own understanding, most of them are Christians. They and those non-Christians believe that the morality of American society. The foundation is Jewish-Christian morality". University of Texas professor Robert Tegelden said: "American culture is a special mixture of Christianity, capitalism and democracy". Finally, the American subject culture is hard work and pioneering. Spirit and self-awareness, its culture highly emphasizes that the individual is the scale of everything, and rationality is the core content of the scale. Therefore, American culture can also be called rational culture. Its distinctive features are: 1) The West is heavy and heavy; 2) Western heavy profits and heavy methods; 3) Western heavy business light farmers [38].

\subsection{Entrepreneur in Western Culture}

The theory of entrepreneurs originated from the West. Entrepreneurs grew up in Western culture and were naturally deeply influenced by them. Max Weber believes that entrepreneurs must constantly make money with money, and that life is for the purpose of making money. This spirit is "transcendence and irrational". Under this kind of spiritual control, people must use everything, the most rational means to achieve the goal. Among them, all the most rational means, simply put, is to regard "making money" as "the duty of heaven", which is also the religious belief in Western culture. Therefore, entrepreneurs who have grown up in Western culture will urgently pursue corporate profits and earn economic benefits. How is Morishima Thom, of the London School of Economics, "How successful is Japan"? The Western Technology and the Japanese National Spirit believe that the Japanese spirit of ensuring corporate success is rooted in a rule-based behavioral model in Japanese history. Enterprises should not be guided solely by economic interests, but should rethink the way in which corporate profits are obtained and the contribution of corporate profits to society.

\section{Research on Confucian Culture}

From the perspective of today's eastern world, it can be roughly divided into three major cultural circles: the Chinese cultural circle, the Indian cultural circle, and the Arab Islamic cultural circle [39]. Because Chinese traditional culture has 
long been in the mainstream of Confucian culture, it has profoundly influenced the way of thinking and moral standards of people in East Asia and even in Asia, such as Japan, South Korea, Singapore and other countries. Chinese traditional culture, especially Confucian culture, has occupied an important position in this region and formed a "Confucian cultural circle" with common values.

\subsection{Definition of Confucian Culture}

In China, Confucian culture has become a mainstream culture with profound historical and political reasons. Chinese culture is based on the family, based on agriculture, and built on a centralized system. It is precisely because of this strong farming culture that the Chinese people's specific social psychology has been cultivated, such as loving peace, pragmatism, diligence and simplicity, self-cultivation and respect for tradition, etc. This is a special result of long-term agricultural society. Historically, during the Spring and Autumn Period and the Warring States Period, Chinese culture reached its peak, especially in Confucianism, France, and Taoism. However, this situation changed. The Emperor $\mathrm{Wu}$ of Han Dynasty practiced the rule of "dismissing 100 schools and respecting Confucianism". Confucianism represented by Confucius then occupied the dominant position of Chinese culture, and the development of Confucian culture runs through China, the main line of culture.

In fact, in the later development, Chinese feudal rulers have always been Confucianism in the promotion of Confucian cultural rule, and they have complemented the Taoism, the law, or the Confucianism, Taoism, and law. Confucianism is also the main culture of China Fusion. For example, Confucianism and Taoism are both opposing and unified ideological systems, and their development has undergone a long process of integration. Xunzi is a master of the philosophies of the philosophers, but in his thoughts, Confucianism has a larger composition. In the process of the integration of Confucianism and Taoism, he was the first thinker to combine Confucianism and Taoism. For example, his famous viewpoint "There is a time when the earth has its own wealth, and the people have its own rule, and the husband is able to participate in it". It is similar to the thought of "the heaven and the earth" of the Simeng School. Therefore, from here on, Confucianism and Taoism began to merge with one another and each took their own strengths. Then, from the Han Dynasty, Confucianism and Taoism also played a very important role in the development of Chinese society. In the hearts of every scholar, Confucianism and Taoism play a very important role, although their composition is not the same. For example, Jia Yi expressed his grand view of the universe and life in "Peng Bird Fu", and he proposed the importance of "making" in the development of the material world. "Made" is Jia Yi's understanding of "Tao" and "German". The former is the category of Taoist thought, the latter is the Confucian understanding of "German". Here is the idea that its thought is compatible with "Tao" and "German" Ingredients. Later, some scholars combined Confucianism, Taoism, and Legalism. "Huainanzi" is such a 
book, the main idea is Taoist thought, but it combines the ideas of Confucianism and Legalism of the predecessors, and gives a new interpretation of the three thoughts, which is inspiring to future generations of scholars.

Therefore, the Confucian culture mentioned in this article is a broad Confucian culture, a combination of the philosophers of the philosophers, rather than the Confucian school alone. The Confucian culture here is a large category, including both the original Confucianism and the later integration of Taoism, Legalism, and Buddhism.

\subsection{Characteristics of Confucian Culture}

Confucian culture has its own distinctive features and is vastly different from Western culture. Some scholars believe that Confucian culture is spiritual, while Western culture is material. For example, Li Dazhao (1918) in his book "The Fundamental Differences between Eastern and Western Civilizations", in simple terms, the Eastern civilization is spiritual, the Western civilization is material; the Eastern civilization is the soul, the Western civilization is the flesh [40]; the Indian thinker and poet Tagore (2002) believes that the East is a spiritual civilization, the West is a material civilization, the East is human, and the West is scientific [41]; the purpose of the East is growing, and the purpose of the West is gaining, fighting for strength, not respecting beauty and truth. The foundation of the East is society, the country can perish, society will still exist, and the foundation of the West is the state, the state is everything, all problems are solved by the state; the East is collective enjoyment, personal work, and the West is personal enjoyment, collective Work; the East is a common source of common ground, establishing coordination in the intricacies, while the West only speaks about action, speaks speed, does not talk about harmony, coordination and rhythm. In addition, domestic scholars have also compared the specific values of Eastern and Western cultures. For example, Chen Duxiu (1915) believes that the cultural differences between the East and the West can be attributed to three points: First, the Western nationality is based on war, and the Oriental people are based on rest; second, the Western nationality is based on the individual, and the Oriental ethnic group is based on the family [42]. Third, the Western nation is based on the rule of law, based on realism, and the Toyo people are based on emotions and based on imaginary text. JiYulin (1992), a master of Chinese studies, believes that the most fundamental difference between Confucian culture and Western culture is the difference in thinking patterns [43]. Western culture pays attention to analysis and divides it into two; while Confucian culture pays attention to synthesis and combines into one. Yu Tiantian (2001) believes that there are differences between China and the United States in three aspects [44]. First, China emphasizes the spirit and the United States emphasizes material; second, China emphasizes "collectivism", the United States emphasizes "individualism", and third, China and the United States' concept of interpersonal communication is different. Yang Chunyuan (1998) believes that due to differ- 
ent factors such as geographical environment, historical background and development process, the cultures of China and the United States also show great differences [36]. These differences are mainly manifested in the following three aspects: first, the concept of hierarchy and human rights; second, the importance of love, sympathy and individualism; third, ethics and the rule of law.

\subsection{Entrepreneurs under Confucian Culture}

Therefore, entrepreneurs in Confucian culture are significantly different from entrepreneurs in Western culture. The biggest difference is highlighted by the difference between the pursuit of interests and the pursuit of morality. Specifically, entrepreneurs in Western culture are influenced by the spirit of Protestant capitalism. They are eager to pursue profits, eager to expand the scale of enterprises, but neglect the social values of enterprises, and this social value is also advocated by traditional Confucian ethics. The famous contemporary scholar Mr. Tang Yijie believes that if the most reasonable way to make profits (making money) as a means, and "public interest" (that is, "righteousness") as the "purpose", this is a Chinese enterprise that conforms to Chinese Confucian ethics family spirit [45].

\section{Conclusions}

All in all, whether they are Western economists or domestic scholars, they define the special group of entrepreneurs according to their own research purposes or different priorities, so most of them only reflect a certain cultural situation or enterprise, one aspect of the nature of the family, but failed to fully reveal what entrepreneurs should be [46]. On the one hand, for entrepreneurs research conducted by Western scholars, they use economic methods in Western cultural contexts to study, define the definition, function and role of entrepreneurs, and form a certain entrepreneurial theory system, but mainstream economics is neglected, and later development is relatively weak. On the other hand, when Western economics was introduced to China, domestic scholars began to conduct entrepreneurial theoretical research on the domestic situation. They defined entrepreneurs from a certain aspect or a certain angle, summed up the characteristics of entrepreneurs or differentiated entrepreneurs. The relationship of capitalists, but did not form a certain system of entrepreneurial theory. Based on the above research status, the author has seen some research gaps, which are summarized as follows:

First of all, domestic and foreign research on entrepreneurs does not form a clear definition. Although there are many studies, most scholars study entrepreneurs from a certain angle or purpose. The definitions formed are only applicable to certain preconditions, but not to the general situation.

Second, existing research lacks a cultural perspective of entrepreneurial theory integration. The Western theory of entrepreneurial theory is relatively mature, and a corresponding entrepreneurial theory system has been formed, but the en- 
vironment it forms is completely in the Western cultural context, and it does not apply to Confucian scenes that are significantly different from Western culture. The study of entrepreneurial theory tends to focus on a specific perspective or research purpose, and ignores the cultural differences between the East and the West. It fails to form the integration of entrepreneurial theories under the unique Confucian cultural context, and ultimately does not form a corresponding theoretical system.

Finally, from the perspective of research methods, most of the researches on entrepreneurial theory at home and abroad are based on the methods of literature research and deductive reasoning. A few of them use case studies and mathematical modeling methods. It is rare. Among them, for most domestic research, they mostly carry out literature analysis and theoretical derivation, and then make recommendations. They have not conducted field investigations and empirical research, so the conclusions and opinions are not convincing.

In summary, this study combines the research results of predecessors, from the perspective of Confucian culture, using multi-case and rooted theory research methods, sums up the connotation dimension of entrepreneurs with Confucian cultural characteristics, in order to form our oriental entrepreneurial theory. A systematic model corrects long-standing misconceptions about Chinese entrepreneurs and urges entrepreneurs to focus on product or service quality.

\section{Conflicts of Interest}

The author declares no conflicts of interest regarding the publication of this paper.

\section{References}

[1] Kirzner, I. (2009) Entrepreneurs and the Entrepreneurial Function: A Commentary. Social Science Electronic Publishing, New York.

[2] Jiang, J.-Q. (2005) Innovative Contract Choice and Entrepreneurship. Economics. Quarterly, 4, 101-118.

[3] Cantillon, R. (1986) Introduction to the Nature of Business. The Commercial Press, Beijing.

[4] Smith, A. (2009) The Wealth of Nations. Shanghai Sanlian Bookstore, Shanghai.

[5] Knight, F.H. (2006) Risk, Uncertainty and Profit. China Chief Accountant, 1, 71-71.

[6] Geer, D. (2009) An Investigation of the Formation and Distribution of Wealth. The Commercial Press, Beijing.

[7] Karl, M. (1995) Selected Works of Marx and Engels. Volume 1. People's Publishing House, Beijing, 39-53.

[8] Say, B. (1997) Introduction to Political Economy, The Commercial Press, Beijing.

[9] Alfred, L. and Chandler, D. (1987) Visible Hand: The Management Revolution of American Enterprises. The Commercial Press, Beijing.

[10] Marshall, A. (2010) Introduction to the Principles of Economics. Tianjin People's Publishing House, Tianjin. 
[11] Sombart, W. (1958) Modern Capitalism (Vol. I). The Commercial Press, Beijing.

[12] Wang, J.-Z. (2005) Entrepreneur Concept-A Review of Theory. Journal of Hubei University of Economics, 3, 77-82.

[13] Schumpeter, J. (1991) Economic Development Theory. The Commercial Press, Beijing.

[14] Hayek, F.V.H. and Deng, Z.-L. (1997) Principles of Free Order. Sanlian Bookstore, Beijing.

[15] Kirzner, I.M. (1973) Competition and Entrepreneurship. University of Chicago Press, Chicago.

[16] Leibenstein, H. (1968) Entrepreneurship and Development. American Economic Review, 8, 72-83.

[17] Loasby, B.J. (1998) The Entrepreneur: An Economic Theory. The Entrepreneur. An Economic Theory, 93, 931-932. https://doi.org/10.2307/2232766

[18] Coase, R.H. (1937) The Nature of the Firm. Economica, 4, 386-405. https://doi.org/10.1111/j.1468-0335.1937.tb00002.x

[19] Williamson, O.E. (1999) The Economic Institutions of Capitalism. Firms, Markets, Relational Contracting. China Social Sciences Press, Beijing.

[20] Demsetz, H. and Springs, S. (1990) Theory of Property Rights. Comparison of Economic and Social Systems, 6, 49-55.

[21] Zhang, C.-L. (1994) Enterprise Organization and Market System. Shanghai People's Publishing House, Shanghai.

[22] Zhang, W.-Y. (2015) Enterprise's Entrepreneur: Contract Theory. Shanghai People's Publishing House, Shanghai.

[23] Huang, Q.-H. (2003) Entrepreneur Incentives and Constraints and State-Owned Enterprise Reform. Renmin University of China Press, Beijing.

[24] Hong, Y.-X. (2000) Research on the Transformation of Economic Growth Mode. Nanjing University Press, Nanjing.

[25] Cheng, C.-P. and Wei, M.-X. (2002) Entrepreneur Human Capital Development.

[26] Liu, M.-S. (1994) Cultivating Professional Entrepreneurial Classes. Economic Research, 6, 56-61.

[27] Zhou, Q.-R. (2005) What Would Be the Value of Not Recognizing the Human Capital of Entrepreneurs? Chinese Entrepreneur, 5, 54-56.

[28] Ding, D.-H. and Liu, Z.-W. (1999) From Human Capital to Heterogeneous Human Capital. Productivity Research, 3, 7-9.

[29] Li, Z.-M. and Zhao, S. (2007) Analysis of the Formation of Entrepreneur Human Capital. Contemporary Finance and Economics, 8, 70-73.

[30] Zhang, D.-D. and Li, W. (1998) Discussion on the Functions, Roles and Conditions of Entrepreneurs. Economic Research, 8, 29-33.

[31] Li, Y. (1999) Entrepreneur Is a Quality rather than a Position. Chinese businessman, 11, 9-9.

[32] Wang, G.-C. (2002) Corporate Governance Structure and Entrepreneur Choice. Economic Management Press, Beijing.

[33] Cheng, G.-P. (2002) Operator incentives. Economic Management Press, Beijing.

[34] Xu, Z.-J. (1997) Innovation Profit and Entrepreneurial Intangible Assets. Economic Research, 8, 47-50. 
[35] Ji, Y.-L. (1999) The Hedong of the Jubilee, the Hexi of the Jubilee-Oriental Cultural Integration, General Preface. LingnanWenshi, 2, 4-8.

[36] Yang, C.-Y. (1998) A Review of Cultural Differences between China and the United States. Journal of Yantai University (Philosophy and Social Sciences Edition), 3, 58-61.

[37] Chen, F.-J. (2000) The Similarities and Differences between Eastern and Western Cultures and the Absorption of Western Culture by Oriental Culture. International Forum, 3, 62-68.

[38] Weber, M. (1987) The Protestant Ethic and the Spirit of Capitalism. Unwin paperbacks, London.

[39] Ji, Y.-L. (1991) Comparative Literature and Folk Literature-Comparative Literature Research Series of Peking University. Peking University Press, Beijing.

[40] Li, D.-Z. (1918) The Fundamental Difference between Eastern and Western civilizations. Journal of Yanji, 3, 45-50.

[41] Yin, X.-N. (2002) Tagore's View of Civilization and Its Response in the East and West. Sichuan University, Sichuan.

[42] Dong, K.-J. and Chen, D.-X. (1986) The Differences between the Fundamental Thoughts of the Eastern and Western Nationalities. Chinese Modern Literature Research Series, 3, 309-310.

[43] Ji, Y.-L. (1992) Oriental Culture and Oriental Literature. Literary and Art Controversy, 4, 4-6.

[44] Yu, Y.-T. (2001) Differences between Chinese and American Cultures and Business Behaviors. Economic Management, 5, 72-74.

[45] Tang, Y.-J. (2009) Confucian Ethics and Chinese Modern Entrepreneurship. Jianghan Forum, 1, 5-9.

[46] Zhao, Y. (2013) Concept Definition of Entrepreneur. Contemporary Economy, 8, 126-128. 